\title{
Party Politics
}

http://ppq.sagepub.com/

\section{Party Mobilization and Political Participation in New and Old Democracies}

Jeffrey A. Karp and Susan A. Banducci

Party Politics 2007 13: 217

DOI: $10.1177 / 1354068807073874$

The online version of this article can be found at:

http://ppq.sagepub.com/content/13/2/217

Published by:

(SAGE

http://www.sagepublications.com

On behalf of:

Political Organizations and Parties Section of the American Political Science Association

Additional services and information for Party Politics can be found at:

Email Alerts: http://ppq.sagepub.com/cgi/alerts

Subscriptions: http://ppq.sagepub.com/subscriptions

Reprints: http://www.sagepub.com/journalsReprints.nav

Permissions: http://www.sagepub.com/journalsPermissions.nav

Citations: http://ppq.sagepub.com/content/13/2/217.refs.html 


\title{
PARTY MOBILIZATION AND POLITICAL PARTICIPATION IN NEW AND OLD DEMOCRACIES
}

\author{
Jeffrey A. Karp and Susan A. Banducci
}

\begin{abstract}
Political parties play a pivotal role by mobilizing citizens to participate in the political process. This may be particularly important in new democracies, where party attachments are weak and voter turnout is low. Using data drawn from the Comparative Study of Electoral Systems (CSES), we examine citizens' reported contact with political parties during a national campaign across a range of democracies. We find that rates of reported contact are lower in new democracies and that on average citizens appear to be less engaged in the political process. Nevertheless, parties in new democracies appear to be more likely to target citizens than in old democracies. Their efforts lead them to be just as successful at stimulating political participation.
\end{abstract}

KEY WORDS - CSES - party mobilization a political development

\section{Introduction}

Political participation is widely believed to be an important indicator of the health and vitality of democracy. Political parties can help to facilitate participation by encouraging citizens to become engaged in the political process. This pivotal role for parties in engaging citizens was recognized 40 years ago to be particularly important in emerging democracies, where parties serve as the primary instruments of political socialization (Weiner and LaPalombara, 1966). Recent literature on new democracies has also emphasized this important role of political parties (Kitschelt et al., 1999; Lipset, 1994; Mainwaring, 1999). In this article, we use survey data from a range of countries that include both new and old democracies to examine how citizens' contact with political parties in the context of a national election stimulates political participation. We find that citizens from new 
democracies are less likely to be contacted by parties and candidates and are consequently less likely to be engaged in the political process. There are, moreover, predictable differences in campaign activity across new and old democracies. Nevertheless, party mobilization matters and is a significant predictor of not only voting but other forms of political engagement in both new and old democracies.

\section{Party Mobilization}

Party contacting efforts are a reflection of both party organizational strength and strategic considerations. Strategically, parties are expected to expend greater efforts at getting their supporters out when the benefits exceed the costs. These strategic considerations are influenced by incentives produced by the electoral system as well as the party system. For example, parties may contact more voters under proportional systems, where the extra votes are more likely to produce extra seats (Cox, 1999). Additionally, these contacting efforts will be easier when parties have greater organizational resources.

Mainwaring $(1998,1999)$ has suggested that party institutionalization is the main factor that distinguishes party systems in new and old democracies. Institutionalized party systems are characterized by stable and strong partisan attachments, low electoral volatility, trust in parties and elections, and well-resourced parties that are not dominated by a single personality. While newer democracies tend to have weak party institutionalization (Mainwaring, 1998), little is known about how mobilization strategies of parties differ across new and old democracies. In new democracies, where partisan attachments are likely to be weak (see Dalton and Weldon, 2007) or parties and elections may lack legitimacy, parties may need to exert greater efforts in getting potential supporters to the polls.

Several features of party systems in new democracies suggest, however, that it may be difficult to mobilize voters. While parties in Western democracies are becoming increasingly professionalized as expenditures and national staff increase (Farrell and Webb, 2002), parties in newer democracies are likely to be poorly organized, poorly resourced and inexperienced in mobilization efforts (Birch, 2005). The lack of widespread and stable party membership is likely to make canvassing efforts more difficult. New democracies may also lack the organizational expertise and material resources to hire political consultants to coordinate a canvassing campaign.

Regardless of the amount of resources, parties everywhere have an incentive to reduce the costs of mobilization efforts by targeting probable voters and targeting voters that are less costly to reach. Several voter characteristics may make them easier to contact or identify as probable voters: citizens who are known to have a history of participating in previous elections or members of groups such as unions are some examples of characteristics that could be used to identify probable voters. Identifying supporters and 
probable voters may be more difficult in new democracies. Weak partisan attachments and voter volatility, for example, may make it more difficult for parties to identify potential supporters.

While new and old democracies may well have different levels of party activity, another question is whether the kinds of voters targeted across systems are the same. If parties pursue a mobilization strategy (as opposed to a conversion strategy), they are also likely to contact members of the population that are predisposed to vote, support their candidate and get others to vote (Rosenstone and Hansen, 1993). On the other hand, parties may pursue a conversion strategy by contacting potential voters in the hope of persuading them to vote for them. Parties may be particularly inclined to pursue this strategy in compulsory voting countries or in other countries where turnout is already high. Empirical evidence about the influence of party contact on vote choice suggests that such efforts may be successful but have a more limited impact (Denver et al., 2004; Marsh, 2004). Lower turnout in new democracies (Karp and Banducci, 1999; Norris, 2004) suggests that parties may be more inclined to pursue a pure mobilization strategy rather than conversion. However, greater electoral volatility in new democracies suggests that parties may have success when pursuing a conversion strategy. The targeting of voters, i.e. supporters, probable voters or potential converts, requires organizational resources on the part of political parties.

Aside from the stage of political development, the type of electoral systems may also influence the likelihood that citizens will come into contact with parties or candidates (Karp et al., forthcoming). On the one hand, proportional representation (PR) systems are known to have higher turnout than single-member plurality systems (Blais and Dobrzynska, 1998; Lijphart, 1999). Some have reasoned that proportional systems foster greater party mobilization efforts because parties have an incentive to mobilize everywhere (Powell, 1986). In those districts that are non-competitive, voters have less of an incentive to vote and parties have less of an incentive to mobilize (Powell, 1980: 12).

On the other hand, while every vote may count equally in PR systems, candidates are less likely to have an incentive to campaign on a personal level, especially in districts with a large district magnitude. In candidate-based systems, candidates have an incentive to cultivate a personal vote and consequently have a greater incentive to contact voters. Additionally, having geographically defined districts with a single member elected simplifies the process of identifying which voters to contact and which candidates are responsible for the contacting. In one of the few studies to examine how party mobilization varies by system, Karp et al. (forthcoming) find that voters are more likely to come into contact with parties and candidates in candidatebased systems than in PR systems. Thus, while PR may well be associated with higher levels of turnout the mechanism that produces the turnout may not be that of party contacting. Many new democracies, particularly those 
that are former communist countries, have adopted mixed systems which combine a party list with single-member districts (Birch, 2001). Therefore, there is an incentive or opportunity for candidates in these new democracies with mixed systems to develop a personal vote through contacting efforts.

\section{Effectiveness of Party Contact}

Rational choice models assume that citizens will participate in elections if the costs exceed the expected benefits from the act of participation. Mobilization can affect both the perceived costs and benefits of voting so that the costs are lowered and the perceived benefits are greater. Parties may reduce the costs of voting by supplying information about candidates or even arranging transportation to the polls. Party contact may also make citizens aware of the importance of their votes. As Denver and Hands (1974: 35) argue: 'Higher turnout in marginal seats is rarely the product of a "rational" appreciation of the situation by voters, but results from parties creating greater awareness amongst voters or simply cajoling them into going to the polls.'

Experimental studies beginning with Gosnell (1927) and extended by Gerber and Green (2000) have demonstrated that citizens are more likely to vote when they are contacted. Similar results have been found outside the United States (Bochel and Denver, 1971, 1972). Most survey-based studies also show that reported contact by a party has a positive impact on turnout in the United States (Caldeira et al., 1990; Kramer, 1970; Rosenstone and Hansen, 1993; Wielhouwer and Lockerbie, 1994). This general conclusion has been extended to countries such as the United Kingdom (Whitely and Seyd, 1994), Ireland (Marsh, 2004) and New Zealand (Karp and Banducci, 2004). Declining party mobilization efforts in general have been blamed for the decline in turnout in the United States (Rosenstone and Hansen, 1993) and in New Zealand (Vowles, 2002). Other studies suggest that party mobilization can extend beyond voting to other campaign activities (Huckfeldt and Sprague, 1992) and civic volunteerism (Pattie et al., 2003).

The evidence on the effects of party contact summarized above is based on single-country studies and, while suggestive, tells us little about the relative rates of contacting during different stages of political development. Characteristics of weakly institutionalized party systems in addition to decreasing the probability of contacting citizens may also influence the effectiveness of party contact in mobilizing voters. This will depend not only on the ability of parties to target a large number of potential voters but also on their ability to convert potential voters to actual voters. Potential voters are more likely to respond to contact when they trust those initiating the contact. Evidence based on post-Communist countries suggests that political parties are among the most distrusted political institutions (Rose, 1995) and a lack of legitimacy is an indicator of weak party institutionalization (Mainwaring, 1998). Therefore, we should expect parties in established 
democracies to be more likely to target certain groups and be more successful in their efforts than those in new democracies.

Below we examine how rates of contact and the effectiveness of contact vary across a range of democracies that vary by both political development and institutional design. We have two sets of questions to address in our empirical work. First, we assess the impact of political development on party campaigns and party contact with voters. Second, we assess the effectiveness of party contact on the decision to participate in the political process. Our approach is to rely on individual level data measuring citizens' reported contact with political parties and candidates in the context of a national campaign. This has the advantage of allowing us to more directly assess the characteristics that parties use in their contacting efforts. Indeed, in general, we know very little about either the effects of democratic development on party mobilization efforts or, at the micro-level, about party attempts to mobilize voters in new democracies. In addition, we can assess whether the effectiveness of the contact on voting and other forms of political participation varies across new and old democracies.

\section{Data}

The Comparative Study of Electoral Systems (CSES) provides a useful source for testing these hypotheses. Module 2 includes the following question designed to measure party mobilization: 'During the last campaign did a candidate or anyone from a political party contact you to persuade you to vote for them?'1 To date, over 20 election studies conducted between 2001 and 2004 have been deposited with the CSES Secretariat and made available through an Advance Release (29 June 2005 version). ${ }^{2}$ Of the 23 countries used in this analysis, 7 are classified as new democracies. ${ }^{3}$

As measures of political participation we consider not only voter turnout, which is assumed to be the most common form of participation, but also other political activities. These include a measure of whether a respondent reports trying to persuade others to vote for a particular party or candidate. We also examine more active political engagement in the campaign, measured by the following question: 'Did you show your support for a particular party or candidate by, for example, attending a meeting, putting up a poster, or in some other way?'

Figure 1 shows the proportion of citizens who reported being contacted by a political party or candidate across the 23 countries in our sample. The United States is one of three countries that has an unusually high level of mobilization. As Figure 1 reveals, almost half of the electorate reported being contacted by a political party in the United States in the 2004 election. While the figure is high by comparative standards, survey data from previous national elections indicate that party mobilization has been on the rise (Banducci and Karp, 2001; Goldstein and Ridout, 2002). Ireland has the 


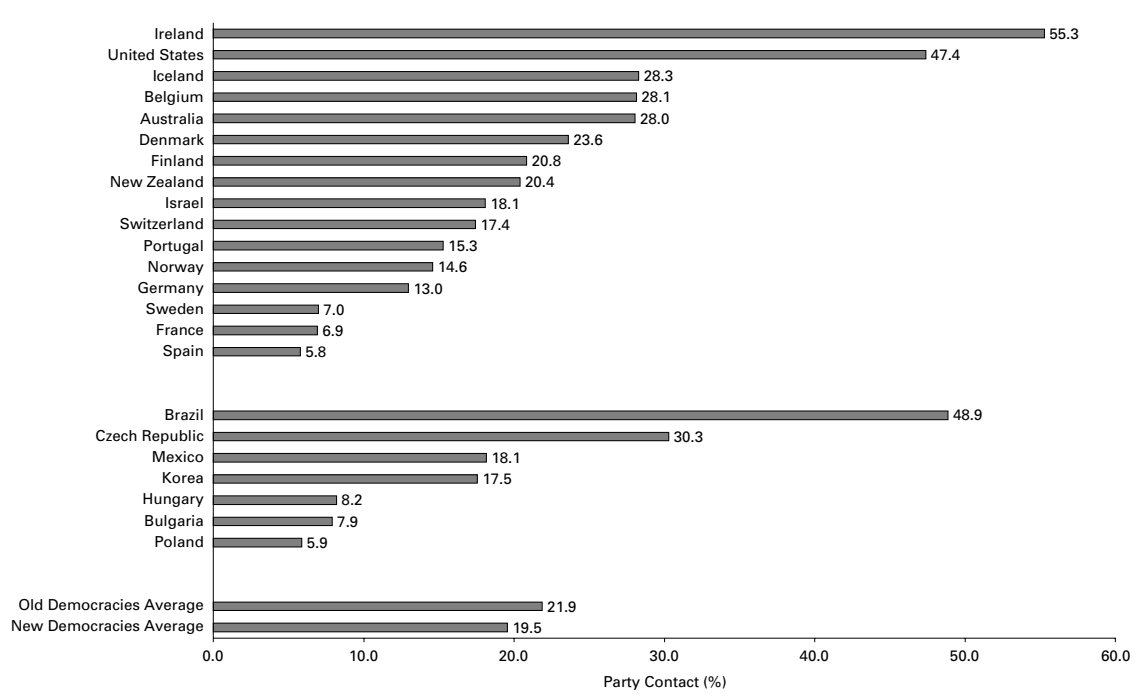

Figure 1. Party contact by new and old democracies

highest degree of party activity in the sample, with a majority ( 55 percent) reporting that they were contacted by candidates or parties in 2002. The large proportion reporting contact is said to be a consequence of the personal nature of Irish campaigns, as all political parties and candidates make an extensive effort to knock on as many doors as possible during the official campaign (Marsh, 2004). Such a high degree of party activity was also evident in the 1999 European Elections with over 70 percent reporting in Ireland that they were canvassed by a political party (Karp et al., 2003). The CSES data indicate that Brazil and the Czech Republic also have high levels of mobilization. According to Samuels (2001), campaigns in Brazil are among the most expensive in the world because candidates must spend lavishly to distinguish themselves in an increasingly competitive party system. Mexico and Korea have levels of contact similar to the older democracies, while Hungary, Bulgaria and Poland have comparatively low levels. Among the old democracies, Spain has the lowest level of contact. Portugal, the other country with the most recent transition to democracy, is also at the low end of contact along with France and Sweden.

\section{Explaining Party Mobilization}

To examine the determinants of party mobilization, we test a model that assesses the relative importance of the factors that are assumed to influence party activity. The CSES measure of party contact does not explicitly ask whether parties or candidates attempted to encourage their supporters to go to the polls. Nevertheless, if parties are following this strategy then they 
will contact those who are more likely to support the party, such as their own partisans. On the other hand, if parties adopt a conversion strategy they should be expected to contact non-partisans who will be more easily persuaded to change their minds. This can be tested by including a measure of whether a citizen feels close to a political party, which is analogous to the measure of party identification used in the American National Election Study (Barnes et al., 1988).

As suggested above, electoral systems are assumed to play a role in shaping party activity. The classification of electoral systems is the subject of a considerable literature within political science (for a comprehensive review, see Farrell, 2001; see also Lijphart, 1999). Here we are simply interested in whether a system is candidate or list based following the expectation that candidates will have a greater incentive to mobilize voters when their names appear on the ballot. We also make a further distinction between open and closed party lists.

Of potentially more consequence is the number of parties in a particular system: more parties should produce more campaign activity everything else being equal. The effective number of parties, a measure that takes into account both the number of parties and their relative size is used as an indictor for this purpose. ${ }^{4}$ We also control for the competitiveness of the election by taking the difference between the top two vote-getters. ${ }^{5}$ We anticipate that parties will be more likely to engage in mobilization efforts when they have the greatest potential to impact the outcome of an election. When turnout is low, mobilization efforts are likely to make the greatest impact. Therefore we include turnout in the model as a control.

Citizens who have previously had some contact with political parties or politicians may be more likely to be politically connected and consequently are more easily reached (see Rosenstone and Hansen, 1993). The CSES includes several measures of prior non-campaign political involvement. The questions are explicit about activity taking place over the last five years and include the following activities: (1) contacting a politician or government official, (2) taking part in a protest, march, or demonstration, and (3) working together with people who share the same concern. Although these are all forms of prior political activity, we include them as separate measures to examine whether persons who engage in a particular activity are more likely to be contacted. Additionally, members of associations with political ties may be more likely to be contacted, so a dummy variable for union membership is included. Finally, we included a battery of standard demographic controls for party contact including age, education and gender.

Since the dependent variable is dichotomous, logistic regression is used to estimate the models. Because of the multi-level structure of the data, most conventional methods of estimation will underestimate standard errors leading to a higher probability of rejection of a null hypothesis. Therefore, the models are estimated using robust standard errors clustered by country. The procedure does not affect the coefficients but it does estimate more 
consistent standard errors even when some of the assumptions about variance are violated.

Table 1 reports the results of the model predicting party contact. We present the results for both new and old democracies as well as a pooled model that tests for differences between old and new democracies. In the pooled model the institutional variables hypothesized to influence party activity are significant and in the expected direction. The greater the number of effective parties the more likely citizens are to report having been contacted. The effects are particularly strong in the new democracies, while there is no significant difference in the model that includes just the old democracies. ${ }^{6}$ Candidate-based systems appear to be more likely to have greater party mobilization. This appears to be driven by Ireland, which has the highest level of party contact (see Figure 1$).{ }^{7}$ In the new democracies the sign is negative but not significant. Competition is in the expected direction in the new democracies; negative values indicate that citizens are less likely to be contacted when there is a bigger difference between the top two vote-getters. Turnout is also negative, as predicted, but only in the new democracies.

Turning to the individual characteristics, we find that parties in new democracies are more likely to contact party loyalists than are those in old

Table 1. Explaining party mobilization

\begin{tabular}{|c|c|c|c|c|c|c|}
\hline & \multicolumn{2}{|c|}{ New democracies } & \multicolumn{2}{|c|}{ Old democracies } & \multicolumn{2}{|c|}{ All } \\
\hline & Coef. & $\begin{array}{l}\text { Robust } \\
\text { S.E. }\end{array}$ & Coef. & $\begin{array}{l}\text { Robust } \\
\text { S.E. }\end{array}$ & Coef. & $\begin{array}{l}\text { Robust } \\
\text { S.E. }\end{array}$ \\
\hline Non-voter & $-0.25^{*}$ & $(0.12)$ & -0.12 & $(0.15)$ & -0.12 & $(0.09)$ \\
\hline Write & $0.91 * *$ & $(0.06)$ & $0.78 * *$ & $(0.07)$ & $0.84 * *$ & $(0.07)$ \\
\hline Work & $0.68 * *$ & $(0.06)$ & $0.44 * *$ & $(0.09)$ & $0.56^{* *}$ & $(0.08)$ \\
\hline Protest & $0.36 * *$ & $(0.13)$ & -0.03 & $(0.12)$ & 0.03 & $(0.11)$ \\
\hline Age & -0.01 & $(0.01)$ & 0.00 & $(0.00)$ & 0.00 & $(0.00)$ \\
\hline Female & -0.08 & $(0.07)$ & $-0.09 * *$ & $(0.03)$ & $-0.08 * *$ & $(0.03)$ \\
\hline Close to party & $0.18^{\dagger}$ & $(0.09)$ & 0.08 & $(0.10)$ & 0.12 & $(0.09)$ \\
\hline Education & $0.06^{* *}$ & $(0.02)$ & 0.05 & $(0.03)$ & 0.03 & $(0.03)$ \\
\hline Open list & $-1.40 * *$ & $(0.18)$ & $0.60 *$ & $(0.31)$ & $0.74 * *$ & $(0.26)$ \\
\hline $\begin{array}{l}\text { Candidate-based } \\
\text { system }\end{array}$ & $-1.76^{* *}$ & $(0.20)$ & $1.02 * *$ & $(0.38)$ & $1.07 * *$ & $(0.44)$ \\
\hline (Lack of) & & & & & & \\
\hline Competitiveness & $-0.10 * *$ & $(0.00)$ & 0.00 & $(0.03)$ & -0.01 & $(0.02)$ \\
\hline Union member & 0.15 & $(0.11)$ & 0.21 & $(0.13)$ & 0.15 & $(0.11)$ \\
\hline Turnout & $-0.04 * *$ & $(0.01)$ & -0.01 & $(0.01)$ & 0.00 & $(0.01)$ \\
\hline $\begin{array}{l}\text { Effective number } \\
\text { of parties }\end{array}$ & $0.47 * *$ & $(0.05)$ & 0.05 & $(0.07)$ & $0.14 *$ & $(0.06)$ \\
\hline New democracies & - & - & - & & 0.06 & $(0.47)$ \\
\hline Constant & -0.66 & $(0.33)$ & 1.72 & $(0.99)$ & 3.05 & $(1.07)$ \\
\hline Pseudo- $R^{2}$ & 0.28 & & 0.10 & & 0.09 & \\
\hline$n$ & 10,881 & & 24,076 & & 34,957 & \\
\hline
\end{tabular}

$* * p<0.01 ; * p<0.05 ;{ }^{\dagger} p=0.05$. Standard errors are adjusted for clustering on country. Pseudo- $R^{2}$ estimated by McKelvey and Zavoina's method. 
democracies. This suggests that parties in new democracies may be more likely to follow a strategy of mobilization, while those in established democracies may be reaching out beyond their core base of support to convert rather than mobilize other voters. ${ }^{8}$ Parties everywhere appear to be more likely to contact those voters who are predisposed to vote. This is evident by the positive coefficients for education, prior voting history and strength of party preference. As discussed earlier, parties that adopt a mobilization strategy may target politically active people because they are easier to motivate to get to the voting booth and they are more likely to convince their friends to vote. Also, parties may just find it easier to locate politically active people from lists of campaign contributors or party members. Finally, it should be noted that the fit of the model is noticeably better in the new democracies. ${ }^{9}$ One might have expected the fit to be better in the established democracies if the professionalization of parties enables them to more easily target citizens. Instead, what this suggests is that parties in established democracies are less predictable in their efforts and are likely targeting a broader segment of the electorate. This has the potential to be a successful strategy to the extent that parties do not concentrate their efforts on those predisposed to vote (as the new democracies appear to do). On the other hand, trying to mobilize a broader segment of the electorate may be less effective.

\section{Effects of Mobilization on Political Participation}

Table 2 provides an initial look at political participation across new and old democracies. Reported turnout varies from a low of 58 percent in Poland to 95 percent in Germany and Denmark. These figures almost certainly reflect a degree of over-reporting. ${ }^{10}$ Nevertheless, the differences across countries are similar to aggregate turnout figures. Switzerland and the United States typically have the lowest levels of turnout, while Denmark and Australia are usually recognized as having a high level of turnout. New democracies appear to have lower turnout, which is largely consistent with previous literature relying on aggregate data (Norris, 2004). Citizens also appear to be less likely to discuss politics in the new democracies. On average, just 15 percent of the respondents in new democracies report trying to persuade others to vote for a particular party or candidate, while 23 percent report having done so in the old democracies. However, there is considerable variation across the new democracies. Brazil, the Czech Republic and Korea have relatively high percentages of citizens reporting political persuasion. But in all but one of the remaining countries, the percentages are all lower than in any of the old democracies. The two countries with the lowest levels of turnout, Mexico and Poland, were also among the lowest in political persuasion. The proportion reporting some kind of campaign activity is low in both new and old democracies. ${ }^{11}$ On average, just 1 in 10 respondents 
Table 2. Political participation by old and new democracies

\begin{tabular}{|c|c|c|c|}
\hline & Reported vote & Persuade others & Campaign activity \\
\hline \multicolumn{4}{|l|}{ Old Democracies } \\
\hline Germany & 94.8 & 27.7 & 6.5 \\
\hline Denmark & 94.6 & 22.1 & 7.7 \\
\hline Australia & 91.9 & 32.4 & 16.3 \\
\hline Iceland & 91.3 & 22.1 & 16.2 \\
\hline Israel & 89.2 & 32.3 & 10.9 \\
\hline Spain & 88.9 & 7.7 & 5.7 \\
\hline Sweden & 88.4 & 12.8 & 3.1 \\
\hline Belgium & 85.7 & 12.0 & 7.2 \\
\hline Ireland & 85.3 & 13.0 & 8.6 \\
\hline New Zealand & 83.6 & - & 5.8 \\
\hline Norway & 82.7 & 17.3 & 6.5 \\
\hline Finland & 80.0 & 12.5 & 11.4 \\
\hline France & 79.1 & 29.0 & 6.9 \\
\hline United States & 76.4 & 44.1 & 29.9 \\
\hline Portugal & 74.5 & 9.6 & 7.2 \\
\hline Switzerland & 68.2 & 15.0 & 6.0 \\
\hline Average & 84.7 & 20.6 & 9.7 \\
\hline \multicolumn{4}{|l|}{ New Democracies } \\
\hline Brazil & 85.9 & 36.5 & 18.0 \\
\hline Hungary & 82.7 & 15.3 & 9.8 \\
\hline Bulgaria & 78.9 & 7.0 & 6.5 \\
\hline Korea & 78.3 & 20.5 & 4.1 \\
\hline Czech Republic & 73.3 & 25.7 & 20.1 \\
\hline Mexico & 71.8 & 8.9 & 12.9 \\
\hline Poland & 58.2 & 7.1 & 4.1 \\
\hline Average & 75.6 & 17.3 & 10.8 \\
\hline
\end{tabular}

report being active in the campaign. The United States is clearly an outlier, with 30 percent reporting some campaign activity and 44 percent reporting trying to persuade others to vote a certain way. No other country comes close to this level of activity; an intriguing finding given that turnout in the United States is among the lowest in the world. ${ }^{12}$

To what extent does party mobilization help to explain these differences in political participation? As is evident from Figure 2, the same countries low on party contacting also have the lowest levels of campaign activity. Indeed, the aggregate levels of party contact and campaign activity are highly correlated. These same countries also had the highest degree of campaign activity among the new democracies. To test whether a relationship exists at the individual level, we model political participation as a function of party contact and control for social and demographic attributes. We also include several contextual variables in the model. Given that proportional 


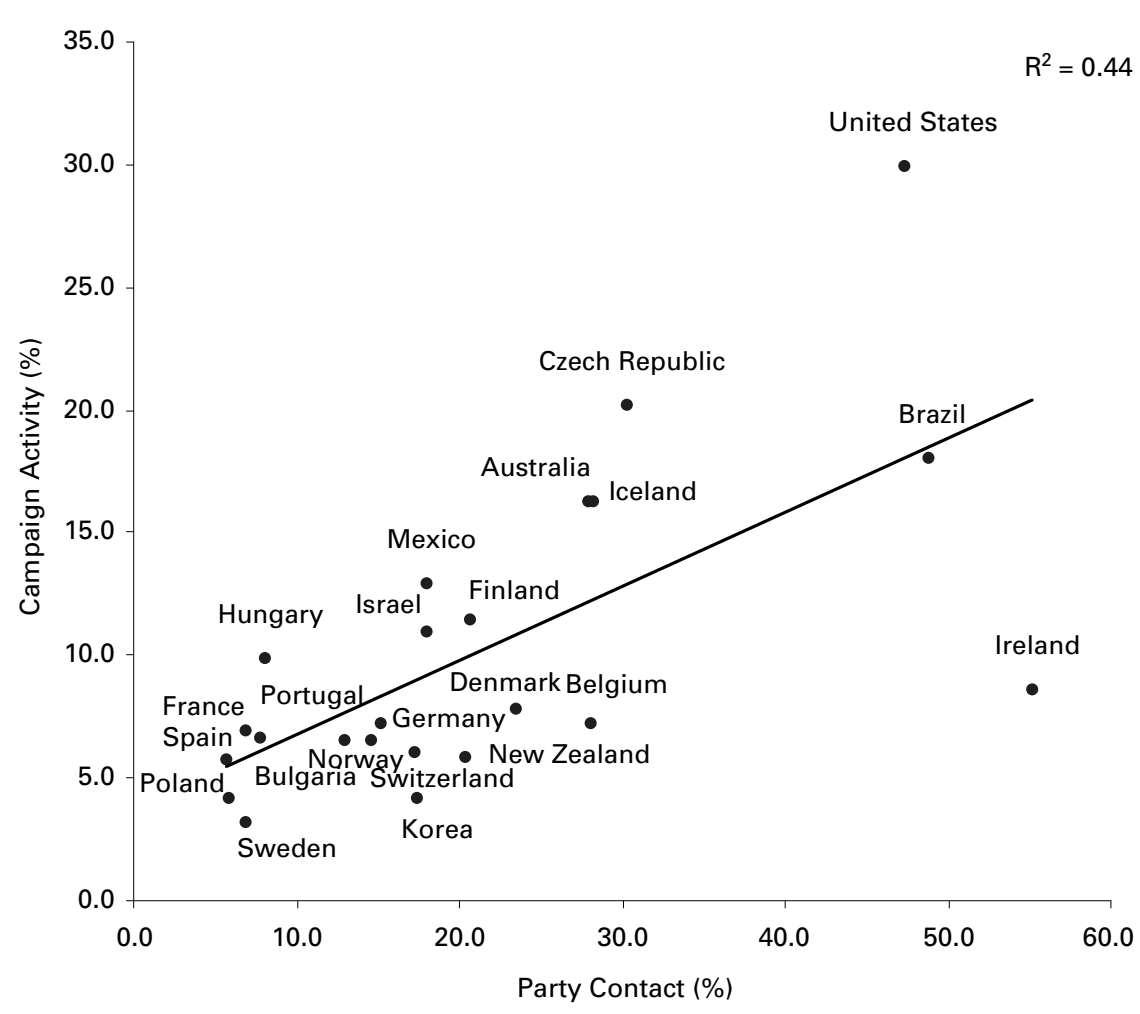

Figure 2. Relationship between party mobilization and campaign involvement

systems are associated with higher turnout, we include a measure of disproportionality in the models predicting political participation to capture the effects of the electoral system. ${ }^{13}$ Other institutional characteristics, such as compulsory voting have been known to increase turnout in both old (Franklin, 2003) and new democracies (Fornos et al., 2004). Compulsory voting rules might also encourage citizens to become politically involved in other ways. Therefore a dummy variable is included in all of the models predicting political participation.

In these models, however, our main variables of interest are those concerning party contact - the dependent variable in Table 1 . Party contact should increase the likelihood of voting and it should also influence other political activities. Since our primary interest is to assess the effects of mobilization, we include additional variables that control for past activity and that affect the probability of being contacted. These include prior voting and prior non-campaign-related political activity based on the three measures of political activity discussed above. ${ }^{14}$

As Table 3 shows, the impact that these campaign efforts have on an individual's likelihood of voting is statistically significant even when controlling 
Table 3. Mobilization and political participation

\begin{tabular}{|c|c|c|c|c|c|c|}
\hline & \multicolumn{2}{|c|}{ Reported vote } & \multicolumn{2}{|c|}{ Persuade others } & \multicolumn{2}{|c|}{ Campaign activity } \\
\hline & Coef. & $\begin{array}{l}\text { Robust } \\
\text { S.E. }\end{array}$ & Coef. & $\begin{array}{l}\text { Robust } \\
\text { S.E. }\end{array}$ & Coef. & $\begin{array}{l}\text { Robust } \\
\text { S.E. }\end{array}$ \\
\hline Non-voter & $-1.96 * *$ & $(0.13)$ & -0.12 & $(0.11)$ & -0.18 & $(0.13)$ \\
\hline Write & 0.13 & $(0.07)$ & $0.63 *$ & $(0.06)$ & $0.87 * *$ & $(0.08)$ \\
\hline Work & 0.11 & $(0.07)$ & $0.62 * *$ & $(0.07)$ & $0.93 * *$ & $(0.11)$ \\
\hline Protest & $0.26^{*}$ & $(0.11)$ & $0.40 * *$ & $(0.10)$ & $0.53 * *$ & $(0.09)$ \\
\hline Age & 0.00 & $(0.00)$ & 0.00 & $(0.00)$ & $0.01 * *$ & $(0.00)$ \\
\hline Female & -0.02 & $(0.04)$ & $-0.21 * *$ & $(0.04)$ & $-0.12 *$ & $(0.05)$ \\
\hline Close to party & $0.70 * *$ & $(0.10)$ & $0.82 * *$ & $(0.08)$ & $1.20 * *$ & $(0.09)$ \\
\hline Education & $0.08 * *$ & $(0.02)$ & $0.09 *$ & $(0.02)$ & 0.01 & $(0.03)$ \\
\hline $\begin{array}{l}\text { (Lack of) } \\
\quad \text { Competitiveness }\end{array}$ & -0.01 & $(0.01)$ & -0.02 & $(0.01)$ & $-0.03 *$ & $(0.01)$ \\
\hline Disproportionality & $-0.05^{*}$ & $(0.02)$ & $-0.09 * *$ & $(0.03)$ & -0.01 & $(0.02)$ \\
\hline Compulsory voting & $0.47^{*}$ & $(0.20)$ & 0.18 & $(0.49)$ & 0.00 & $(0.23)$ \\
\hline New democracies & -0.21 & $(0.25)$ & $0.62 *$ & $(0.26)$ & $0.63 * *$ & $(0.17)$ \\
\hline Party contact & $0.43 * *$ & $(0.09)$ & $0.62 * *$ & $(0.09)$ & $0.90 * *$ & $(0.09)$ \\
\hline Constant & 0.15 & $(0.29)$ & 2.38 & $(0.27)$ & 3.90 & $(0.27)$ \\
\hline Pseudo- $R^{2}$ & 0.25 & & 0.19 & & 0.27 & \\
\hline$n$ & 34,957 & & 33,293 & & 34,822 & \\
\hline
\end{tabular}

$* * p<0.01 ; * p<0.05$. Standard errors are adjusted for clustering on country.

Pseudo- $R^{2}$ estimated by McKelvey and Zavoina's method.

Note: New Zealand is missing in the persuade model.

for past activity. These effects, however, are not substantial given that citizens are already predisposed to vote. Furthermore, parties and candidates appear to contact those who are most likely to vote (see Table 1). Specifically, when all other variables are set to their mean values a person who is contacted by a party or candidate is expected to increase by about 4 percent. In models not reported here, the coefficient for contact doubles in size when prior voting and past activity are omitted from the model. Country-specific models were also estimated that indicate that party contact is a positive and significant predictor of voting in nine of the countries in the sample. ${ }^{15}$ The effects were strongest in the United States and Poland both countries with low turnout - and Finland and Bulgaria. When considering the proportion of voters contacted (see Figure 1), parties in the United States and to a lesser extent Finland stand out as being the most effective in mobilizing voters to go to the polls.

The contextual variables are all in the expected direction. Disproportionality, for example, is negative, which is consistent with most of the empirical studies of turnout (see, for example, Franklin, 2003). Compulsory voting also helps to increase the likelihood that a citizen will vote. While competitiveness is in the expected direction it is not statistically significant.

The results for the political persuasion model indicate that the effects of mobilization have more of an influence. Specifically, the probability of engaging in persuasion when contacted increases by about 9 percent. In 
addition, disproportionality is statistically significant. While compulsory voting helps to stimulate turnout it does not appear to make citizens more engaged in the political process. When controlling for these factors, citizens in new democracies are actually more likely to engage in political persuasion than those citizens in old democracies. ${ }^{16}$ In another model not reported here, we included an interaction term to test whether party mobilization was more effective in new democracies. The term was positive and significant, indicating that when contacted citizens in new democracies are more likely to become involved than in old democracies. In the turnout model, the slope for party contact in new democracies is larger than for old democracies, but a test of the interaction term revealed that the effect of party contact for new versus old democracies on turnout was not statistically significant.

The final model predicts campaign involvement and is similar to that of the previous model. While the coefficient for party mobilization is larger in this model, when all other variables are held constant at their means, the predicted probability of becoming involved in the campaign is lower $(6$ percent). Like the political persuasion model, citizens in new democracies are more likely to be involved with the political process when controlling for these factors, but the difference is not as great. ${ }^{17}$ Country-specific models indicate that party contact has a positive and significant effect in all the countries in the sample, with the exception of Australia.

\section{Conclusion}

Our results confirm that parties serve an important function in electoral politics. When citizens are contacted by parties they are more likely to vote and more likely to participate in the campaign than are citizens who are not contacted. Furthermore, citizens are not likely to be contacted at random. Some parties invest heavily in their mobilization efforts and are likely to be more successful when they are able to target their potential supporters and those likely to vote. Our analysis suggests that parties in new democracies are more likely to target specific types of voters. This is surprising given the fact that parties in these democracies are almost certainly less professionalized than those in the established democracies. Although we have no data on campaign finance, we might assume that parties in new democracies are not as well funded and consequently must be more careful with how they allocate their resources. Cross-national differences in levels of reported contact do suggest that parties in new democracies are likely to reach fewer voters. The exceptions are Brazil and the Czech Republic, where the level of contact is greater than in most of the countries in our sample.

Party mobilization may be particularly important in increasing political engagement and participation in new democracies. Overall, citizens in these countries appear to be less engaged in the political process and, on average, 
reported turnout is about 10 percent lower. Citizens in new democracies are also less likely to report trying to persuade others to support a particular party or candidate. However, our findings do suggest that party contact in new democracies has the potential to be just as successful in engaging citizens and encouraging participation as in older democracies.

Greater political participation may also lead to greater satisfaction with the political process. When citizens participate, they are more likely to be satisfied with political institutions and the system as a whole (Finkel, 1987). Similarly, Clarke and Acock (1989) suggest that once those who have previously been discouraged from participating become involved, the very act of doing so may increase internal efficacy. This may be especially important in emerging democracies. Ultimately, then, how actively parties engage citizens to participate in the process may well have systematic consequences for democratic stability.

\section{Notes}

An earlier version of this article was presented at the conference on Political Parties and Political Development, National Democratic Institute, Washington, DC on 31 August 2005.

1 Unfortunately, the question does not specify the nature of the contact, whether it was a personal visit, telephone call or campaign letter. The question asks about contact from a candidate or party; therefore, we are likely to capture campaign contacts in candidate-based and party list systems. However, we will not be able to distinguish who made the actual contact in order to test whether more candidate (versus party) contacts are made in candidate-based systems.

2 Hong Kong is not included in the analysis because it is not a sovereign country. Taiwan was also excluded because of the low response rate that may have contributed to the skewed nature of some of the key variables used in this analysis. For example, 73 percent of the respondents reported having been contacted by a political party. This figure is about 20 percent higher than any other country in the analysis and about 50 percent higher than the average for all countries. Two election studies were deposited from Germany. We use the telephone survey. Where available we have weighted the data by the sample weight (B1010_1) to adjust for unequal selection probabilities and other features of the sample design (CSES, 2005).

3 Spain and Portugal are classified as old democracies since they have had a continuous history of democracy for over 20 years.

4 The new democracies in the CSES sample have an average of 4.5 effective parties, while the old democracies have on average 5.0 effective parties.

5 We would have preferred to rely on district level data for this purpose. However, data are missing from some of the countries, so for consistency we rely on national differences.

6 Karp et al. (forthcoming) find a negative association between the number of effective parties and contact in seven established democracies. 
7 Data from European Elections confirm Ireland's high degree of party contact. Of the 15 European Union countries, Ireland's level of contact was the highest, with over 70 percent of the electorate being canvassed (Karp et al., 2003).

8 We acknowledge that while the evidence is suggestive it is impossible to be certain with the data at hand because we do not know whether those who feel close to a party were contacted by that party or a different party.

9 This is also the case when the contextual variables are omitted from the model indicating that the better fit is not the result of institutional factors.

10 Previous studies have suggested that social desirability is a trait that may be shared by everyone, though others have found evidence that non-voters who report voting are less likely to do so in countries where the norm of participation is low (Karp and Brockington, 2005). Either way, over-reporting is not likely to present a problem because the error is either systematic or it is reduced in cases where non-voters comprise a larger proportion of the sample.

11 The CSES question asks: 'Did you show your support for a particular party or candidate by, for example, attending a meeting, putting up a poster, or in some other way?'

12 Powell (1986) notes the paradox and suggests that the reason for it lies in institutional barriers that reduce voter turnout in the United States.

13 The measure is based on Gallagher's least squares index and is based on the results from the election when the survey was conducted.

14 It is also possible that those who are more committed to voting may be more likely to remember being contacted by a political party. If so, then the causal arrow may be the other way around.

15 Germany was the only country where party contact was negatively related to voting. The coefficient, however, was not statistically significant.

16 The difference is about 9 percent, holding all other variables constant at their mean values.

17 The difference is about 4 percent, holding all other variables constant at their mean values.

\section{References}

Banducci, Susan A. and Jeffrey A. Karp (2001) 'Mobilizing American Voters: A Reassessment'. Paper prepared for presentation at the Annual Conference of the American Political Science Association, San Francisco, CA, USA on 30 August to 2 September.

Barnes, Samuel H., M. Kent Jennings, Ronald Inglehart and Barbara Farah (1988) 'Party Identification and Party Closeness in Comparative Perspective', Political Behavior 10: 215-31.

Birch, Sarah (2001) 'Electoral Systems and Party Systems in Europe East and West', Perspectives on European Politics and Society 2: 35-77.

Birch, Sarah (2005) 'Single-member District Electoral Systems and Democratic Transition', Electoral Studies 24: 281-301.

Blais, André and Agnieszka Dobrzynska (1998) 'Turnout in Electoral Democracies', European Journal of Political Research 33: 239-61.

Bochel, John M. and David D. Denver (1971) 'Canvassing, Turnout and Party Support: An Experiment', British Journal of Political Science 1: 257-69. 
Bochel, John M. and David D. Denver (1972) 'The Impact of the Campaign on the Results of Local Government Elections', British Journal of Political Science 2: 239-43.

Caldeira, Gregory A., Aage R. Clausen and Samuel C. Patterson (1990) 'Partisan Mobilization and Electoral Participation', Electoral Studies 9: 191-204.

Clarke, Harold D. and Alan C. Acock (1989) 'National Elections and Political Attitudes: The Case of Political Efficacy', British Journal of Political Science 19: 551-62.

Cox, Gary (1999) 'Electoral Rules and the Calculus of Mobilization', Legislative Studies Quarterly 3: 387-419.

Dalton, Russell J. and Steven Weldon (2007) 'Partisanship and Party System Institutionalization', Party Politics 13(2): 179-96 (this issue).

Denver, David and Gordon Hands (1974) 'Marginality and Turnout in British General Elections', British Journal of Political Science 4: 17-35.

Denver, David, Gordon Hands and Ian McAllister (2004) 'The Electoral Impact of Constituency Campaigning in Britain, 1992-2001', Political Studies 52: 289-306.

Farrell, David M. (2001) Electoral Systems: A Comparative Introduction. London and New York: Palgrave.

Farrell, David M. and Paul Webb (2002) 'Political Parties as Campaign Organizations', in Russell J. Dalton and Martin P. Wattenberg (eds) Parties without Partisans: Political Change in Advanced Industrial Democracies, pp. 102-28. Oxford: Oxford University Press.

Finkel, Steven E. (1987) 'The Effects of Participation on Political Efficacy and Political Support: Evidence from a West German Panel', Journal of Politics 49: 441-64.

Fornos, Carolina A., Timothy J. Power and James C. Garand (2004) 'Explaining Voter Turnout in Latin America, 1980 to 2000', Comparative Political Studies 37: 909-40.

Franklin, Mark N. (2003) Voter Turnout and the Dynamics of Electoral Competition. Cambridge: Cambridge University Press.

Gerber, Alan S. and Donald P. Green (2000) 'The Effects of Canvassing, Telephone Calls, and Direct Mail on Voter Turnout: A Field Experiment', American Political Science Review 94: 653-63.

Goldstein, Kenneth M. and Travis N. Ridout (2002) 'The Politics of Participation: Mobilization and Turnout over Time', Political Behavior 24: 3-29.

Gosnell, Harold F. (1927) Getting-Out-the-Vote: An Experiment in the Stimulation of Voting. Chicago, IL: University of Chicago Press.

Huckfeldt, Robert and John Sprague (1992) 'Political Parties and Electoral Mobilization: Political Structure, Social Structure, and the Party Canvass', American Political Science Review 86: 70-86.

Karp, Jeffrey A. and Susan A. Banducci (1999) 'Political Efficacy and Participation in Nineteen Countries.' Paper presented at the Annual Conference of the American Political Science Association, Atlanta, Georgia.

Karp, Jeffrey and Susan Banducci (2004) 'Political Parties and Party Mobilisation', in Jack Vowles, Peter Aimer, Susan Banducci, Jeffrey Karp and Raymond Miller (eds) Voters' Veto: The 2002 Election in New Zealand and the Consolidation of Minority Government, pp. 104-16. Auckland: Auckland University Press.

Karp, Jeffrey A., Susan A. Banducci and Shaun Bowler (forthcoming) 'Getting Out the Vote: Party Mobilization in Comparative Perspective', British Journal of Political Science, in press. 
Karp, Jeffrey A., Shaun Bowler and Susan A. Banducci (2003) 'Electoral Systems, Party Mobilization, and Turnout: Evidence from the European Parliamentary Elections', British Elections and Parties Review 13. London: Frank Cass Publishers.

Karp, Jeffrey A. and David Brockington (2005) 'Social Desirability and Response Validity: A Comparative Analysis of Over-Reporting Voter Turnout in Five Countries', Journal of Politics 67: 825-40.

Kramer, Gerald H. (1970) 'The Effects of Precinct-Level Canvassing on Voting Behavior', Public Opinion Quarterly 34: 560-72.

Kitschelt, Herbert, Zdenka Mansfeldova, Radoslaw Markoswki and Gabor Toka (1999) Post Communist Party Systems: Competition, Representation and InterParty Cooperation. Cambridge: Cambridge University Press.

Lijphart, Arend (1999) Patterns of Democracy: Government Forms and Performance in Thirty-Six Countries. New Haven, CT: Yale University Press.

Lipset, Seymour Martin (1994) 'The Social Requisites of Democracy Revisited', American Sociological Review 59: 1-22.

Mainwaring, Scott (1998) 'Party Systems in the Third Wave', Journal of Democracy 9: 67-81.

Mainwaring, Scott (1999) Rethinking Party Systems in the Third Wave of Democratization: The Case of Brazil. Stanford, CA: Stanford University Press.

Marsh, Michael (2004) 'None of That Post-Modern Stuff Around Here: Grassroots Campaigning in the 2002 Irish General Election', British Elections and Parties Review 14. London: Frank Cass Publishers.

Norris, Pippa (2004) Electoral Engineering: Voting Rules and Political Behavior. Cambridge: Cambridge University Press.

Pattie, Charles, Patrick Seyd and Paul Whiteley (2003) 'Citizenship and Civic Engagement: Attitudes and Behaviour in Britain', Political Studies 51(3): 443-68.

Powell, G. Bingham Jr. (1980) 'Voting Turnout in Thirty Democracies: Partisan, Legal, and Socio-Economic Influences', in R. Rose (ed.) Electoral Participation: A Comparative Analysis, pp. 5-34. Beverly Hills, CA: Sage.

Powell, G. Bingham Jr. (1986) 'American Voter Turnout in Comparative Perspective', American Political Science Review 80: 17-43.

Rose, Richard (1995) 'Mobilizing Demobilized Voters in Post-Communist Societies', Party Politics 1: 549-63.

Rosenstone, Steven J. and John Mark Hansen (1993) Mobilization, Participation, and Democracy in America. London: Macmillan.

Samuels, David (2001) 'Money, Elections and Democracy in Brazil', Latin American Politics and Society 43(2): 27-48.

Vowles, Jack (2002) 'Offsetting the PR Effect? Party Mobilization and Turnout Decline in New Zealand, 1996-1999', Party Politics 8: 587-605.

Weiner, Myron and Joseph LaPalombara (1966) 'The Impact of Parties on Political Development', in J. LaPalombara and M. Weiner (eds) Political Parties and Development, pp. 399-435. Princeton, NJ: Princeton University Press.

Whitely, Paul F. and Patrick Seyd (1994) 'Local Party Campaigning and Electoral Mobilization in Britain', Journal of Politics 56: 242-52.

Wielhouwer, Peter W. and Brad Lockerbie (1994) 'Party Contacting and Political Participation, 1952-90', American Journal of Political Science 38: 211-29. 
JEFFREY A. KARP is Senior Lecturer in Politics at the University of Exeter. His research focuses on comparative political behaviour examining such topics as political mobilization and turnout, minority representation, political attitudes and elite and mass responses to institutional reform. His most recent articles appear in Journal of Politics, British Journal of Political Science and Electoral Studies. ADDRESS: Department of Politics, Amory Building, Rennes Drive, Exeter, Devon EX4 4RJ, UK. [e-mail: j.karp@exeter.ac.uk; URL: www.jkarp.com]

SUSAN A. BANDUCCI is Senior Lecturer in Politics and director of the Centre for European Studies at the University of Exeter. Her research focuses on elections, media, gender and politics and European politics. Her recent publications have appeared in the Journal of Politics and the British Journal of Political Science.

ADDRESS: Department of Politics, Amory Building, Rennes Drive, Exeter, Devon EX4 4RJ, UK. [e-mail: s.a.banducci@exeter.ac.uk; URL: www.banducci.com]

Paper submitted 7 January 2006; accepted for publication 24 June 2006. 